\title{
Colletotrichum acutatum and C. gloeosporioides Species Complexes Associated with Apple in Brazil
}

Rafaele R. Moreira, ${ }^{\dagger}$ Universidade Federal do Paraná, Setor de Ciências Agrárias (SCA-DFF), Curitiba, PR 80035-050, Brazil; Natalia A. Peres, University of Florida, Gulf Coast Research and Education Center (GCREC-UF), Wimauma, FL 33598; and Louise L. May De Mio, Universidade Federal do Paraná, Setor de Ciências Agrárias (SCA-DFF), Curitiba, PR 80035-050, Brazil

\begin{abstract}
Glomerella leaf spot (GLS) is an apple disease that concerns growers due to the increases in severity over the years and the difficulties in control. Species within the Colletotrichum acutatum and C. gloeosporioides species complexes cause GLS, but the proportion of species within each complex in Brazilian apple orchards is not known. The objectives of this study were to identify isolates of Colletotrichum causing GLS on apple orchards in the main Brazilian producing regions to the species level. Two hundred and seven isolates were obtained in orchards in São Paulo (SP), Parana (PR), Santa Catarina (SC), and Rio Grande do Sul (RS)

states. Genomic DNA was extracted, and the ITS, GAPDH, CHS-1, and TUB2 genes were amplified and sequenced. The phylogenetic trees were generated using a concatenated alignment. One hundred and fourteen isolates were identified as belonging to the $C$. acutatum species complex (Cac) and 93 to the $C$. gloeosporioides species complex $(\mathrm{Cgc})$. Five phylogenetic species were identified: C. melonis (1.9\%), C. nymphaeae (47.4\%), C. paranaense (2.4\%), C. limetticola (3.4\%), and C. fructicola $(44.9 \%)$. In SC, Cgc predominates, but in the states of SP, PR, and RS, $\mathrm{Cac}$ was predominant. This is the first report of $C$. limetticola from apple.
\end{abstract}

Glomerella leaf spot (GLS) of apple is a very severe disease in countries where the conditions for the development of epidemics are favorable (Leite et al. 1988; Taylor 1971; Wang et al. 2012). In Brazil, the disease occurs in all producing regions causing severe damage to the Gala cultivar and its clones, which correspond to $60 \%$ of the production area (Petri et al. 2011). In Parana (PR), southern Brazil, isolations have been also made from the Eva cultivar by Hamada (2013), which was previously reported to be resistant to the pathogen (Furlan et al. 2010), and this worries producers in regions where this cultivar is grown.

The symptoms of GLS occur mainly on leaves, although they may also occur on fruit. On leaves, symptoms appear as purple-red spots 2 days after infection, and severe defoliation may occur between 7 and 10 days after infection (Leite et al. 1988; Moreira and May De Mio 2015), reducing productivity in subsequent seasons. GLS is caused by Colletotrichum species that have been reclassified through morphological and molecular methodologies (Damm et al. 2012a, b; Weir et al. 2012) and organized into complexes. New species causing GLS, such as $C$. fructicola belonging to the $C$. gloeosporioides species complex $(\mathrm{Cgc})$, and $C$. karstii, belonging to the $C$. boninense species complex (Cbc), have been reported (Velho et al. 2015).

Bitter rot (BR) in apple is caused by isolates in the same genus and produces symptoms on fruit. Several causal species have recently been reported, such as: C. fioriniae (Shivas and Tan 2009), C. clavatum (Kou et al. 2014), C. godetiae (Baroncelli et al. 2014), C. fragariae (Alaniz et al. 2012), C. karstii, C. nymphaeae, C. fructicola, C. melonis, $C$. theobromicola (Velho et al. 2015), C. abisissum, $C$. paranaense (Bragança et al. 2016), and C. siamense (Munir et al. 2016). These species belong to the $\mathrm{Cgc}, \mathrm{Cbc}$, and $C$. acutatum species complex (Cac) (Damm et al. 2012a, b; Weir et al. 2012).

${ }^{\dagger}$ Corresponding author: R. R. Moreira; E-mail: rafaelemor@gmail.com

Funding: This research was supported by a Brazilian fund (Conselho Nacional de Desenvolvimento Científico e Tecnológico, CNPq) under a project $\mathrm{N}^{\circ} 483566 / 2013-6$. It was also financed in part by the Coorenação de Aperfeiçoamento de Pessoal de Nível Superior - Brazil (CAPES) - Finance Code 001. The last author received research fellowship from National Council for Scientific and Technological Development (CNPq)/Brazil.

Accepted for publication 30 July 2018.

C 2019 The American Phytopathological Society
Due to the short incubation period of GLS, its rapid advance in new areas, its occurrence on cultivars previously reported as resistant, and the occurrence of a large number of new species of Colletotrichum, it is important to understand the proportion and distribution of Colletotrichum species that occur in the Brazilian apple-producing regions to manage the disease adequately.

Therefore, the objectives of this study were to obtain isolates of Colletotrichum causing GLS on apple orchards in all Brazilian producing regions and identify them to the complex and species level.

\section{Materials and Methods}

Isolates. A total of 207 Colletotrichum isolates from apple orchards located in the States of São Paulo (SP), PR, Santa Catarina (SC), and Rio Grande do Sul (RS) were included in this study (Table 1; Fig. 1). Of all the isolates, 14 were from SP, 78 from PR, 80 from SC, and 35 from RS. Isolates were recovered from lesions on tissue surfaces (leaves, flowers, twigs, and buds) that were disinfested by immersion in $70 \%$ alcohol for $30 \mathrm{~s}$ and then in $0.5 \%$ sodium hypochlorite for $30 \mathrm{~s}$. Thereafter, pieces were washed three times with sterile distilled water and plated on potato dextrose agar (PDA) (Himedia, $39 \mathrm{~g} \mathrm{liter}^{-1}$ ). The Colletotrichum colonies were singlespored on PDA and stored dry on filter paper at $-20^{\circ} \mathrm{C}$ in the culture collection of the Federal University of Parana, in Curitiba, Brazil.

Molecular identification and phylogenetic analyses. Genomic DNA used in this study was extracted using the FastDNA Kit (MP Biomedicals, CA, USA) according to the manufacturer instructions. Isolates were initially identified at the complex level with $C$. acutatumspecific primers (CaInt2) (Sreenivasaprasad et al. 1996) and $C$. gloeosporioides-specific primers (CgInt) (Mills et al. 1992). The PCR mixtures contained $14.5 \mu$ l of molecular water (Fischer BioReagents), $5 \mu$ of $5 \times$ PCR buffer (PROMEGA, Madison, WI, USA), $1.5 \mu \mathrm{l}$ of $\mathrm{MgCl}_{2}(25 \mathrm{mM}), 0.5 \mu \mathrm{l}$ of dNTPs $(10 \mu \mathrm{M}), 0.5 \mu \mathrm{l}$ of each primer $(10 \mu \mathrm{M}), 0.5 \mu \mathrm{l}$ of $5 \mathrm{U}$ Taq DNA polymerase (PROMEGA), and $2 \mu \mathrm{l}$ of genomic DNA ( $25 \mathrm{ng}$ ). The PCRs were performed using a T100 Thermal Cycler (BIO-RAD, CA, USA), and the conditions were: an initial denaturation step at $95^{\circ} \mathrm{C}$ for 5 min followed by 33 cycles of $30 \mathrm{~s}$ at $94^{\circ} \mathrm{C}, 55 \mathrm{~s}$ at $58^{\circ} \mathrm{C}$, and $90 \mathrm{~s}$ at $72^{\circ} \mathrm{C}$, and a final extension at $72^{\circ} \mathrm{C}$ for $3 \mathrm{~min}$. The amplicons were visualized in $1 \%$ agarose gel with $1 \times$ TAE buffer $(0.04 \mathrm{M}$ Tris-acetate, $0.0001 \mathrm{M}$ EDTA buffer) + GelRed (Biotium, USA).

Isolates were identified at the species level after amplification and sequencing of the $5.8 \mathrm{~S}$ nuclear ribosomal gene with the two flanking internal transcribed spacers (ITS), an intron of the glyceraldehyde-3phosphate dehydrogenase $(G A P D H)$, and partial sequences of the 
chitin synthase $1(C H S-1)$ and $\beta$-tubulin (TUB2) genes using the primers ITS-1F (Gardes and Bruns 1993) and ITS-4 (White et al. 1990), GDF1 and GDR1 (Guerber et al. 2003), CHS-354R and CHS-79F (Carbone and Kohn 1999), and BT2Fd (Woudenberg et al. 2009) and Bt-2b (Glass and Donaldson 1995), respectively. The PCR reactions were the same for all loci and were performed in a total volume of $25 \mu \mathrm{l}$. The PCR mixtures contained $15.8 \mu \mathrm{l}$ of water, $5 \mu \mathrm{l}$ of $5 \times \mathrm{PCR}$ buffer (PROMEGA), $1.5 \mu \mathrm{l}$ of $\mathrm{MgCl}_{2}(25 \mathrm{mM}), 0.5 \mu \mathrm{l}$ of dNTPs $(10 \mu \mathrm{M}), 0.5 \mu \mathrm{l}$ of each primer $(10 \mu \mathrm{M}), 0.2 \mu \mathrm{l}$ of $5 \mathrm{U}$ Taq DNA polymerase (PROMEGA), and $1 \mu$ l of genomic DNA ( $25 \mathrm{ng}$ ). The PCRs were performed using a T100 Thermal Cycler (BIO-RAD), and the conditions were: an initial denaturation step at $95^{\circ} \mathrm{C}$ for $2 \mathrm{~min}$ followed by 40 cycles of $30 \mathrm{~s}$ at $94^{\circ} \mathrm{C}, 30 \mathrm{~s}$ at $52^{\circ} \mathrm{C}$, and $1 \mathrm{~min}$ at $72^{\circ} \mathrm{C}$, and a final extension at $72^{\circ} \mathrm{C}$ for $5 \mathrm{~min}$. The amplicons were visualized in $1 \%$ agarose gel with $1 \times$ TAE buffer $(0.04 \mathrm{M}$ Tris-acetate, $0.0001 \mathrm{M}$ EDTA buffer) + GelRed (Biotium, USA). The PCR products were purified and sequenced by Genewiz Inc.

The forward and reverse sequences generated were assembled using the software BioEdit (http://www.mbio.ncsu.edu/bioedit/bioedit.html). Sequences of 54 ex-type and other reference strains of species belonging to the $C$. acutatum and $C$. gloeosporioides complexes as well as C. orchidophilum CBS 632.80 (as outgroup), all available on GenBank, were added to the dataset (Table 2), and the sequences were aligned and manually edited with MEGA v.5.2 software (Tamura et al. 2011).

A Neighbor-Joining (NJ) analysis using MEGA v.5.2 software (Tamura et al. 2011), Kimura-2 parameter with Gamma distribution was applied (data not shown), and the closest phylogenetic neighbors were selected for an individual gene region analysis (data not shown) and for a multilocus analysis using ITS, GAPDH, CHS-1, and TUB2 genes. Distance analysis was conducted using Maximum Likelihood (ML), and bootstrap percentages were used to test the hypothesis (1,000 replicates each). The nucleotide substitution model chosen was General Time Reversible (GTR) with a gamma-distributed rate of variation.
Pathogenicity to leaves. For the pathogenicity test, four isolates of each identified species were chosen: C. melonis (33PR, 29SP, 35SP, 34SP), C. nymphaeae (32RSs, 60PR, 89SC, 41SP), C. paranaense (9PR, 10PR, 8PR, 42SP), C. limetticola (27RSs, 49RS, 50RS, 51RS), and C. fructicola (75SC, 58PR, 31RS, 63SC). Apple trees of cultivar Gala were kept in a greenhouse, and the leaves were inoculated by a conidial spray at $10^{4}$ conidia $\mathrm{ml}^{-1}$ with the aid of a manual atomizer (Guarany, São Paulo, Brazil). After inoculation, the plants were transferred to growth chambers at $25^{\circ} \mathrm{C}$ and photoperiod of $12 \mathrm{~h}$ light, and the leaves were covered with plastic bags forming a moist chamber for $24 \mathrm{~h}$. The experimental design was completely randomized with three replicates per isolate; each experimental unit was represented by a twig containing 10 leaves. The type of symptom, the incubation period, and the latency period were evaluated.

\section{Results}

Species identification and phylogenetic analyses. Based on the specific primer molecular analyses, 114 isolates $(55.1 \%)$ obtained in this study belong to the $C$. acutatum species complex, 14 from SP, 70 from PR, 1 from SC, and 29 from RS, and 93 isolates (44.9\%) to the $C$. gloeosporioides species complex, eight from PR, 79 from SC, and six from RS (data not shown).

The ITS, GAPDH, CHS-1, and TUB2 regions of all isolates were successfully amplified and sequenced. The PCR products obtained in their amplification had approximately 550, 250, 300, and 700 base pairs (bp), respectively. High quality sequences of each isolate were used for analyses, and after alignment, differences among the isolates were observed. The nucleotide sequences obtained for all isolates used in this study were deposited in the GenBank database (Table 1).

Of the 114 isolates in the $C$. acutatum species complex that were compared with GenBank sequences (Bragança et al. 2016; Damm et al. 2012a), 98 isolates were identified as C. nymphaeae, 10 from $\mathrm{SP}, 64$ from PR, one from SC, and 23 from RS; four isolates were identified as C. melonis, three from SP and one from PR; five were

Table 1. Isolates of Colletotrichum spp. sampled for this study from apple (Malus domestica) according to the location, cultivar, year, and plant part

\begin{tabular}{|c|c|c|c|c|}
\hline State $^{a}$ & Year & Cultivar & Part of the plant & Isolates \\
\hline SP & 2010 & Eva & Leaf & $\begin{array}{l}\text { 23SP, 27SP, 29SP, 31SP, 32SP, 34SP, 35SP, 37SP, 39SP, 40SP, } \\
\text { 41SP, 42SP, 45SP, 47SP }\end{array}$ \\
\hline \multirow[t]{8}{*}{ PR } & 2011 & Gala & Bud & $\begin{array}{l}\text { 122PR, 123PR, 124PR, 125PR, 126PR, 127PR, 128PR, 129PR, } \\
\text { 130PR, 131PR, 132PR, 133PR, 134PR }\end{array}$ \\
\hline & 2011 & Gala & Leaf & $\begin{array}{l}\text { 56PR, 57PR, 58PR, 59PR, 60PR, 61PR, 62PR, 63PR, 64PR, 65PR, } \\
\text { 66PR, 67PR, 68PR, 69PR, 70PR, 71PR, 116PR, 117PR, 118PR, } \\
\text { 119PR, 120PR, 121PR, 138PR, 142PR, 152PR }\end{array}$ \\
\hline & 2010 & Gala & Bud & 48PR, 49PR, 50PR, 53PR, 55PR \\
\hline & 2010 & Eva & Leaf & $\begin{array}{l}\text { 8PR, 9PR, 10PR, 11PR, 12PR, 14PR, 15PR, 16PR, 17PR, 18PR, } \\
\text { 19PR, 20PR, 21PR, 25PR, 33PR }\end{array}$ \\
\hline & 2011 & Gala & Twig & $\begin{array}{l}\text { 156PR, 157PR, 159PR, 161PR, 162PR, 163PR, 164PR, 165PR, } \\
\text { 166PR, 167PR, 173PR }\end{array}$ \\
\hline & 2010 & Princesa & Leaf & 3PR, 4PR, 5PR \\
\hline & 2011 & Gala & Flower & 176PR, 177PR, 178PR \\
\hline & 2011 & Eva & Flower & 179PR, 180PR, 181PR \\
\hline \multirow[t]{3}{*}{$\mathrm{SC}$} & 2016 & Gala & Leaf & 89SC \\
\hline & 2011 & Gala & Leaf & $105 \mathrm{SC}$ \\
\hline & 2016 & Gala & Leaf & $\begin{array}{l}\text { 1SC, 2SC, 3SC, 4SC, 5SC, 6SC, 7SC, 8SC, 9SC, 10SC, 11SC, } \\
\text { 12SC, 13SC, 14SC, 15SC, 16SC, 17SC, 18SC, 19SC, 20SC, 21SC, } \\
\text { 22SC, 23SC, 24SC, 25SC, 26SC, 27SC, 28SC, 29SC, 30SC, 31SC, } \\
\text { 32SC, 33SC, 34SC, 35SC, 36SC, 37SC, 39SC, 40SC, 41SC, 42S, } \\
\text { 43SC, 45SC, 46SC, 47SC, 48SC, 49SC, 50SC, 51SC, 52SC, 54SC, } \\
\text { 55SC, 58SC, 59SC, 60SC, 61SC, 62SC, 63SC, 64SC, 65SC, 67SC, } \\
\text { 69SC, 70SC, 71SC, 72SC, 73SC, 74SC, 75SC, 76SC, 77SC, 78SC, } \\
\text { 79SC, 81SC, 82SC, 83SC, 84SC, 85SC, 87SC }\end{array}$ \\
\hline \multirow[t]{4}{*}{ RS } & 2015 & Gala & Leaf & $\begin{array}{l}\text { 24RS, 26RS, 27RS, 28RS, 31RS, 32RS, 33RS, 34RS, 44RS, 45RS, } \\
\text { 47RS, 48RS, 49RS, 50RS, 51RS, 52RS, 53RS, 55RS, 58RS }\end{array}$ \\
\hline & 2001 & Gala & Leaf & $\begin{array}{l}\text { 10RSs, } 15 \mathrm{RSs} \text {, 17RSs, 19RSs, 20RSs, 24RSs, 27RSs, 28RSs, } \\
\text { 30RSs, 32RSs }\end{array}$ \\
\hline & 1999 & Gala & Leaf & 39RSs \\
\hline & 2001 & Fuji & Leaf & 2RSs, 3RSs, 4RSs, 6RSs, 7RSs \\
\hline
\end{tabular}

\footnotetext{
${ }^{\mathrm{a}} \mathrm{SP}=$ São Paulo, $\mathrm{PR}=$ Parana, $\mathrm{SC}=$ Santa Catarina, and RS = Rio Grande do Sul.
} 
identified as $C$. paranaense, one from SP and four from PR; and seven were identified as $C$. limetticola, one from PR and six from RS (Table 3; Fig. 2).

Of the 93 C. gloeosporioides species complex isolates that were compared with GenBank (Weir et al. 2012), all isolates were identified as $C$. fructicola, eight from PR, 79 from SC, and six from RS (Table 3; Fig. 3).

Pathogenicity on leaves. All the C. limetticola and C. fructicola isolates inoculated on leaves of the cultivar Gala reproduced the typical symptoms of GLS. The incubation period for these isolates was 2 days and the latency period ranged from 8 to 11 days. Only isolate 32RSs among the $C$. nymphaeae isolates tested reproduced the typical GLS symptom on leaves of the cultivar Gala. Incubation period for this isolate was 2 days and the latency period was 9 days. The other isolates of C. nymphaeae, and C. melonis and C. paranaense did not reproduce typical symptoms of GLS until the end of the evaluation period. These isolates only caused millimeter-diameter necrotic lesions on the leaf limb, and the incubation period varied from

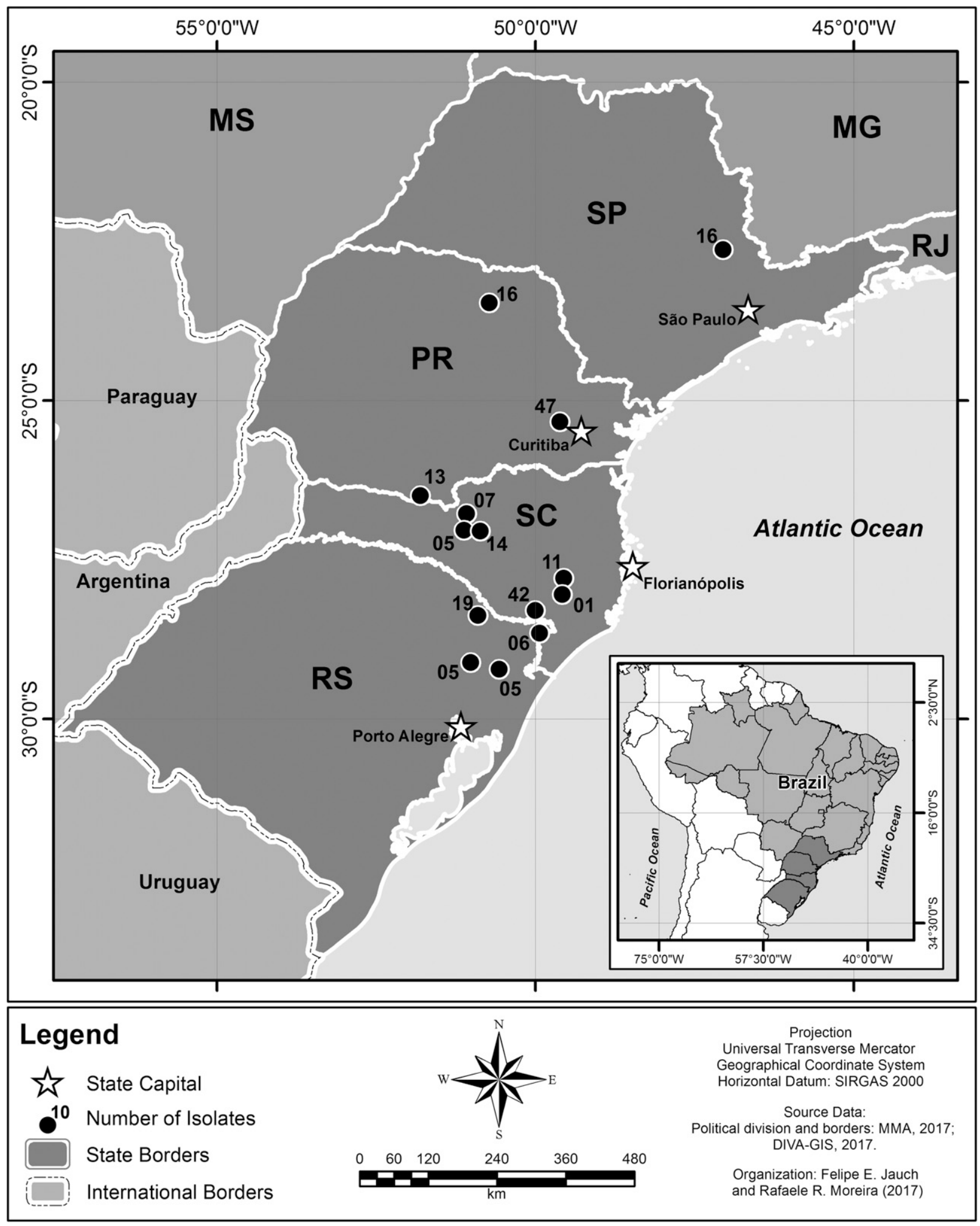

Fig. 1. Map of São Paulo (SP), Parana (PR), Santa Catarina (SC), and Rio Grande do Sul (RS) states of Brazil and locations of Colletotrichum spp. isolate collection. 
3 to 4 days; however, these lesions did not produce reproductive structures of the fungus until the end of the evaluation period (Table 4).

\section{Discussion}

GLS is considered the most severe summer foliar disease in apple orchards in southern Brazil. Failures in chemical control are observed even when growers follow strict intervals of fungicide applications. The results obtained in this study suggest that variations in the Colletotrichum species and complexes may be one potential cause of difficulties in controlling GLS. Colletotrichum isolates from Brazilian apple orchards were identified as belonging to two different complexes: C. acutatum and C. gloeosporioides, and to five phylogenetic species: C. melonis, C. nymphaeae, C. paranaense, C. limetticola, and $C$. fructicola. Among the species identified, $C$. nymphaeae, $C$. melonis, and $C$. paranaense had already been reported as causal agents of BR in Brazil and C. fructicola as a causal agent of GLS and BR (Bragança et al. 2016; Velho et al. 2015). Among apple isolates included in the original description of the Cac and $\mathrm{Cgc}, C$. melonis, C. nymphaeae, C. paranaense, and C. limetticola are from the $\mathrm{Cac}$ and $C$. fructicola from the Cgc were identified (Damm et al. 2012a; Weir et al. 2012).

C. paranaense was first reported by Bragança et al. (2016) as a causal agent of BR in apple. In the present study, isolates of this species were obtained from leaves of the Gala cultivar in PR and from a leaf of the Eva cultivar in SP. C. melonis isolates were obtained from leaves of the Eva cultivar in SP and PR. C. limetticola was isolated in the present study from leaves of the Gala cultivar in RS and from flowers of the Eva cultivar in PR. This is the first report of the occurrence of this species in apple trees. This species has been described and reported by Damm et al. (2012b) on twigs of Citrus aurantifolia; these authors stated that $C$. limetticola is distinguished from other species by $T U B 2$ and $G A P D H$, genes that were also used in the present study. Colletotrichum strains from our study that clustered with strain CBS 114.14 (C. limetticola) have the same ITS and GAPDH sequences as strains from anthracnose on key lime in Florida, USA (KLA-Anderson, HM-1, Ss) (MacKenzie et al. 2009) and in Belize (MTR-KLA-A1) (Peres et al. 2008). In future studies, morphological comparisons will be performed in addition to genetic and pathogenic comparisons.

To understand the epidemiological aspects of plant diseases, it is important that pathogenic species be identified, especially when the variability among species may affect the ability to infect different plant tissues. In our work, C. fructicola and C. nymphaeae were the most frequent species in Brazilian apple orchards. $C$. fructicola was first reported in Thailand causing anthracnose in coffee berry. In addition, it has been identified infecting mandarin, papaya, chili (Phoulivong et al. 2012), mango (Lima et al. 2013), and pear (Jiang et al. 2014), as well as Brazilian apple leaves (Velho et al. 2015; Weir et al. 2012). However, many other hosts are likely affected, but the pathogen is usually only identified to the species complex level as Cgc.

Table 2. Isolates of Colletotrichum spp. in the C. acutatum and C. gloeosporioides complexes used for comparison, with collection details and GenBank accession numbers

\begin{tabular}{|c|c|c|c|c|c|c|c|}
\hline \multirow[b]{2}{*}{ Species } & \multirow[b]{2}{*}{ Accession no. ${ }^{\mathrm{a}}$} & \multirow[b]{2}{*}{ Host } & \multirow[b]{2}{*}{ Country } & \multicolumn{4}{|c|}{ GenBank no. } \\
\hline & & & & ITS & GAPDH & CHS-1 & TUB2 \\
\hline C. limetticola & CBS $114.14 * b$ & Citrus aurantifolia & USA & JQ948193 & JQ948523 & JQ948854 & JQ949844 \\
\hline \multirow[t]{3}{*}{ C. melonis } & CBS $159.84 *$ & Cucumis melo & Brazil & JQ948194 & JQ948524 & JQ948855 & JQ949845 \\
\hline & & Malus domestica & Brazil & KC204986 & KC205020 & KC205037 & KC205054 \\
\hline & CBS 134730, CPC 20912, Col 31 & Malus domestica & Brazil & KC204997 & KC205031 & KC205048 & KC205065 \\
\hline \multirow[t]{3}{*}{ C. nymphaeae } & CBS 129928.216 & Fragaria $\times$ ananassa & USA & JQ948228 & JQ948558 & JQ948889 & JQ949879 \\
\hline & IMI 370491, CPC 18932 & Malus pumila & Brazil & JQ948204 & JQ948534 & JQ948865 & JQ949855 \\
\hline & CBS 515.78* & Nymphaea alba & Netherlands & JQ948197 & JQ948527 & JQ948858 & JQ949848 \\
\hline \multirow[t]{2}{*}{ C. orchidophilum } & CBS 119291, MEP 1545 & Cycnoches aureum & Panama & JQ948154 & JQ948484 & JQ948815 & JQ949805 \\
\hline & CBS $632.80^{*}$ & Dendrobium sp. & USA & JQ948151 & JQ948481 & JQ948812 & JQ949802 \\
\hline \multirow[t]{4}{*}{ C. paranaense } & CBS 134729, Col19, CPC 20901* & Malus domestica & Brazil & KC204992 & KC205026 & KC205043 & KC205060 \\
\hline & IMI 384185, CPC 18937, CPAC 8 & Caryocar brasiliense & Brazil & JQ948191 & JQ948521 & JQ948852 & JQ949842 \\
\hline & IMI345034, CPC 18884 & Fragaria $\times$ ananassa & Australia & JQ948279 & JQ948609 & JQ948940 & JQ949930 \\
\hline & ICMP $18537 *$ & Coprosma sp. & New Zealand & JX010205 & JX010005 & JX009853 & JX010420 \\
\hline \multirow[t]{6}{*}{ C. fructicola } & ICMP 18613 & Limonium sinuatum & Israel & JX010167 & JX009998 & JX009772 & JX010388 \\
\hline & ICMP 18120 & Dioscorea alata & Nigeria & JX010182 & JX010041 & JX009844 & JX010401 \\
\hline & CBS 125395, ICMP 18645 & Theobroma cacao & Panama & JX010172 & JX009992 & JX009873 & JX010408 \\
\hline & ICMP 18581*, CBS 130416 & Coffea arabica & Thailand & JX010165 & JX010033 & JX009866 & JX010405 \\
\hline & CBS 470.96*, ICMP 18187 & Nuphar lutea subsp. & USA & JX010187 & JX009972 & JX009835 & JX010398 \\
\hline & ICMP 17795 & Malus domestica & USA & JX010162 & JX010051 & JX009805 & JX010393 \\
\hline
\end{tabular}

${ }^{a}$ CBS: Culture collection of Centraalbureau voor Schimmecultures, Fungal Biodiversity Centre, Utrecht, The Netherlands; CPC: Working collection of Pedro W. Crous, housed at CBS, Utrecht, The Netherlands; Col: Personal collection of Nelson Massola, housed at ESALQ/USP, Department of Plant Pathology, Piracicaba, Sao Paulo, Brazil; IMI: Culture collection of CABI Europe UK Centre, Egham, UK; ICMP: International Collection of Microorganisms from Plants, Auckland, New Zealand; CPAC: Collection Cpac-Embrapa at Embrapa-Cerrados, Planaltina, DF, Brasil.

$\mathrm{b} *$ indicates ex-holotype or ex-epitype cultures.

Table 3. Frequency of Colletotrichum species isolated from Glomerella leaf spot (GLS) symptoms in orchards located in the states of São Paulo (SP), Paraná (PR), Santa Catarina (SC), and Rio Grande do Sul (RS)

\begin{tabular}{|c|c|c|c|c|c|c|}
\hline \multirow[b]{3}{*}{ State } & \multirow[b]{3}{*}{ Number of isolates } & \multicolumn{5}{|c|}{ Number of isolates per species } \\
\hline & & \multicolumn{4}{|c|}{ Cac } & \multirow{2}{*}{$\frac{C g c}{\text { C. fructicola }}$} \\
\hline & & C. nymphaeae & C. melonis & C. paranaense & C. limetticola & \\
\hline SP & 14 & 10 & 3 & 1 & - & - \\
\hline PR & 78 & 64 & 1 & 4 & 1 & 8 \\
\hline $\mathrm{SC}$ & 80 & 1 & - & - & - & 79 \\
\hline RS & 35 & 23 & - & - & 6 & 6 \\
\hline
\end{tabular}


C. nymphaeae was reported for the first time in Nymphaeae alba and Nuphar luteum (Van Der AA 1978). It has a wide host range, and is currently considered one of the most important strawberry pathogens (Damm et al. 2012a). From the isolates of $C$. nymphaeae identified by Velho et al. (2015), none were able to cause symptoms of GLS, but only symptoms of BR in fruit. In the present study, an isolate of $C$. nymphaeae was able to cause typical GLS leaf symptoms, and thus, this is the first report of this species causing GLS on apple leaves in Brazil and worldwide.

Growers in Brazil typically manage GLS with application of fungicides with different modes of action. It has been reported that species within the Cac were less sensitive to benzimidazoles than members of the Cgc (Adaskaveg and Hartin 1997; Bernstein et al. 1995; Peres et al. 2004). This may suggest that fungicide

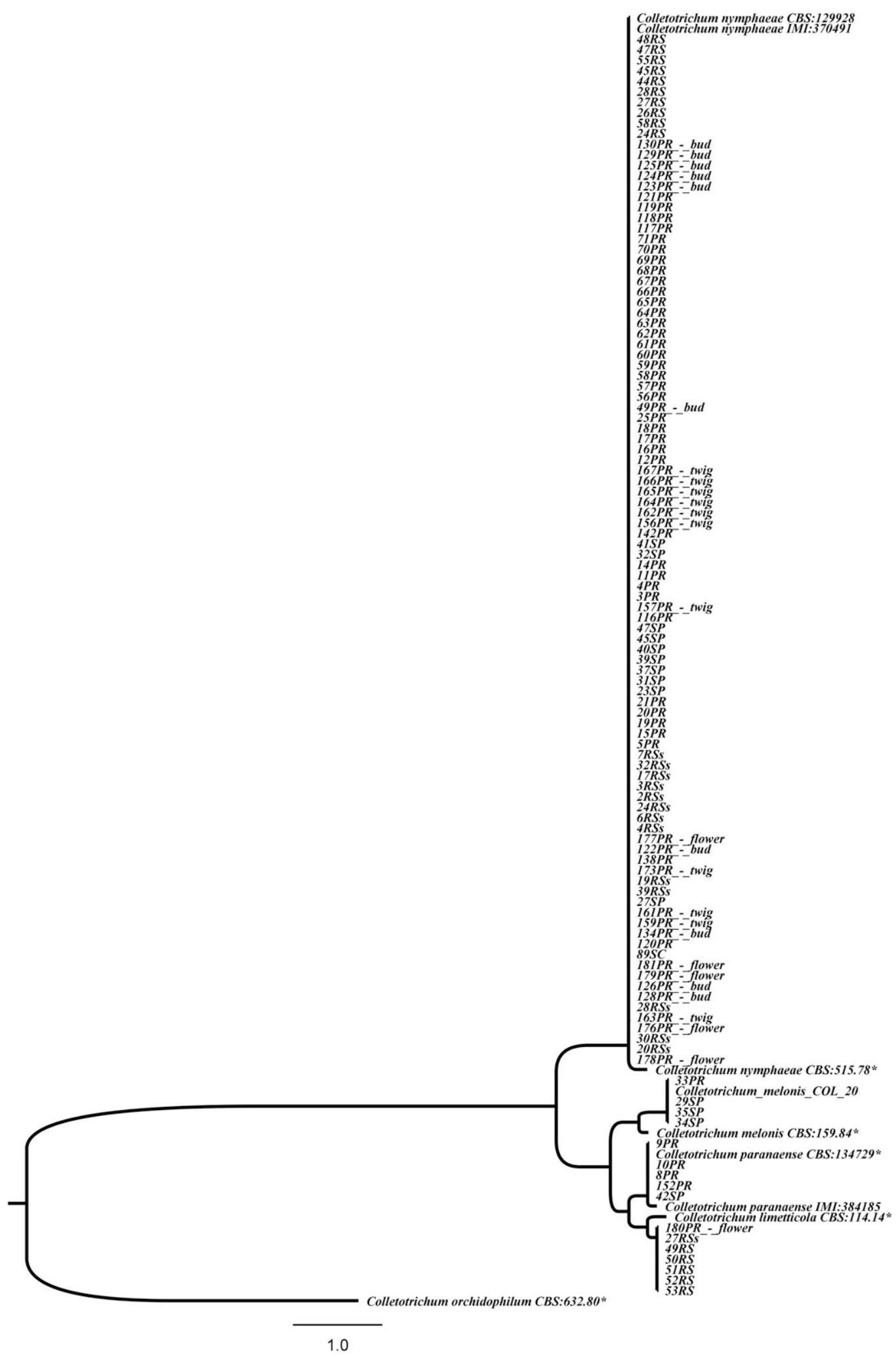

Fig. 2. Phylogenetic tree of Colletotrichum acutatum species complex from apple using the Neighbor-Joining method based on alignment including ITS, GAPDH, TUB2, and CHS-1 concatenated sequences showing the relationship between Colletotrichum species. The evolutionary distances were computed using the Maximum Composite Likelihood method and are in the units of the number of base substitutions per site. The analysis included 176 isolates including the outgroup, C. orchidophilum CBS 632.80 . Values on the branch indicate Bootstrap support of the nodes (1,000 replicates each). * Ex-holotype or ex-epitype cultures. 
use could potentially select for populations with different fungicide sensitivity profiles within commercial orchards. In SC, about $99 \%$ of the isolates collected in this study were identified as $C$. fructicola $(\mathrm{Cgc})$, but in the SP, PR, and RS, species belonging to the Cac predominate, with frequencies of 100,90 , and $83 \%$, respectively.
In this study, no $C$. karstii (C. boninense complex) isolates were found in SC as in the study performed by Velho et al. (2015). C. karstii may be a less competitive species compared to $C$. nymphaeae and C. fructicola species; other evidence for this assertion may be the report of Velho et al. (2015), who found only one isolate of $C$. karstii in Santa Catarina State, but several isolates of $C$. nymphaeae and

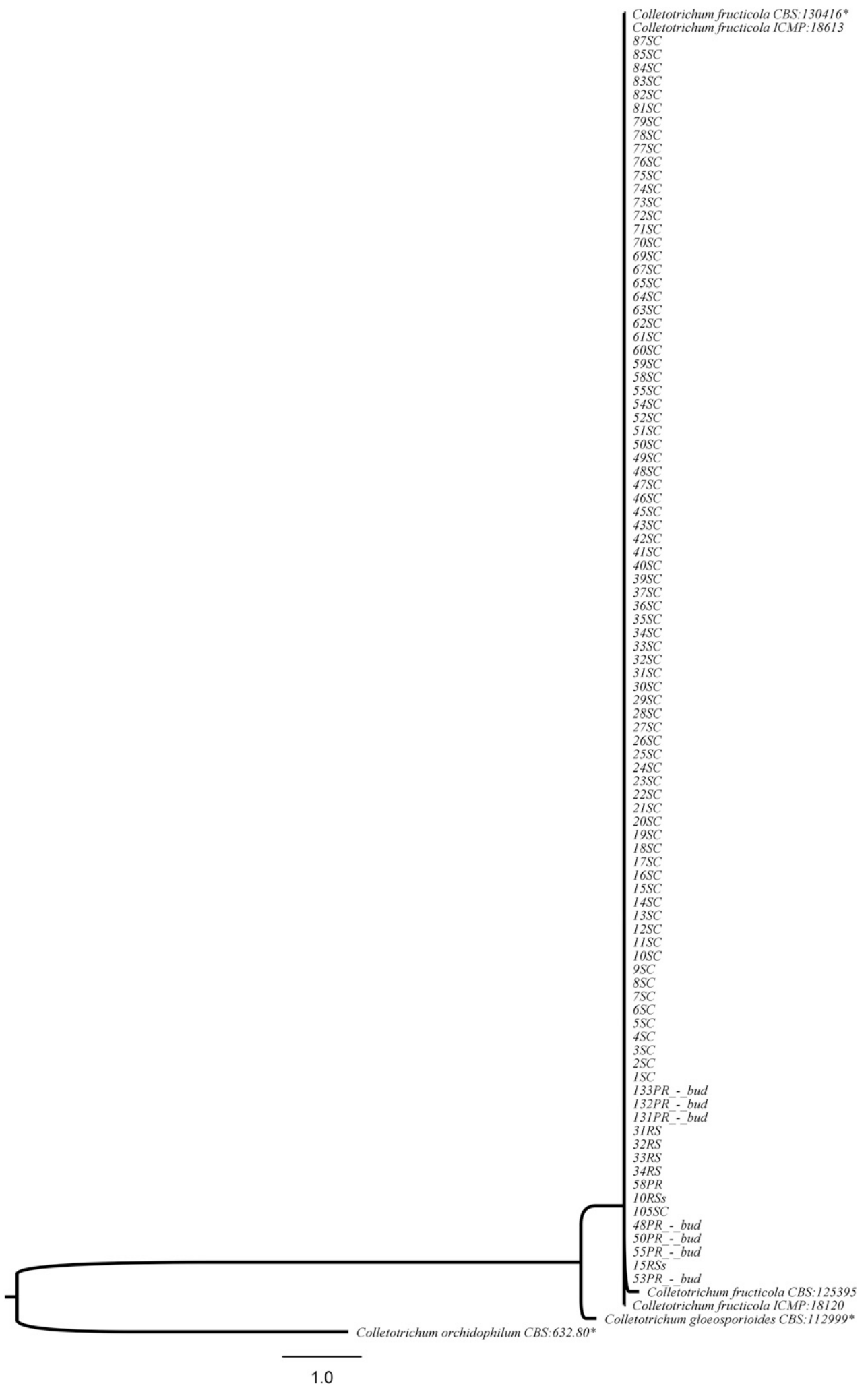

Fig. 3. Phylogenetic tree of Colletotrichum gloeosporioides species complex from apple using the Neighbor-Joining method based on alignment including ITS, GAPDH, TUB2, and CHS-1 concatenated sequences showing the relationship between Colletotrichum species. The evolutionary distances were computed using the Maximum Composite Likelihood method and are in the units of the number of base substitutions per site. The analysis included 142 isolates including the outgroup. C. orchidophilum CBS 632.80 was used as outgroup taxa. Values on the branch indicate Bootstrap support of the nodes (1,000 replicates each). ${ }^{*}$ Ex-holotype or ex-epitype cultures. 
Table 4. Type of symptom, incubation, and latency period of Glomerella leaf spot (GLS) on Gala apple leaves inoculated with species of Colletotrichum isolated from apple orchards in Brazil

\begin{tabular}{lcccc}
\hline Species & $\begin{array}{c}\text { Isolate } \\
\text { code }\end{array}$ & $\begin{array}{c}\text { Type of } \\
\text { symptom }^{\mathbf{a}}\end{array}$ & $\begin{array}{c}\text { Incubation } \\
\text { period (days) }\end{array}$ & $\begin{array}{c}\text { Latency period } \\
\text { (days) }^{\mathbf{b}}\end{array}$ \\
\hline C. melonis & $33 \mathrm{PR}$ & + & 3 & nd \\
& $29 \mathrm{SP}$ & + & 4 & nd \\
& $35 \mathrm{SP}$ & + & 3 & nd \\
C. nymphaeae & $34 \mathrm{SP}$ & + & 3 & nd \\
& $32 \mathrm{RSs}$ & ++ & 2 & 9 \\
& $60 \mathrm{PR}$ & + & 3 & nd \\
& 89SC & + & 3 & nd \\
C. & $41 \mathrm{SP}$ & + & 3 & nd \\
paranaense & $9 \mathrm{PR}$ & + & 3 & nd \\
& $10 \mathrm{PR}$ & + & 3 & nd \\
& 8PR & + & 2 & nd \\
C. limetticola & 42SP & + & 2 & nd \\
& 27RSs & ++ & 2 & 11 \\
& $49 \mathrm{RS}$ & ++ & 2 & 10 \\
& $50 \mathrm{RS}$ & ++ & 2 & 10 \\
C. fructicola & 51RS & ++ & 2 & 9 \\
& $75 \mathrm{SC}$ & ++ & 2 & 9 \\
& $58 \mathrm{PR}$ & ++ & 2 & 8 \\
& $31 \mathrm{RS}$ & ++ & ++
\end{tabular}

$\overline{\mathrm{a}}(+)=$ millimeter-diameter symptom of GLS. $(++)=$ typical symptom of GLS.

$\mathrm{b}$ nd = Not determined since symptoms did not develop during the evaluation period.

C. fructicola. Pathogen evolution can be affected by competition for resources among different strains, and thus, disease control strategies can be improved by knowing the consequences of competition between different pathogenic species (Zhan and McDonald 2013). Competitive ability studies are common in research with isolates with different levels of resistance to fungicides and are suggested for future work (Chen et al. 2016; Karaoglanidis et al. 2011; Ma and Uddin 2009; Pasche and Gudmestad 2008; Veloukas et al. 2014).

The findings in this study demonstrated the diversity of species of Colletotrichum existing in Brazilian apple orchards. Future work might include expansion of apple Colletotrichum collections combined with fungicide sensitivity and efficacy field trials, bearing in mind that the effective control of GLS may depend on the individual characteristics of each Colletotrichum species and their distribution in the apple producing regions. Also, competition and fitness assays comparing species found among distinct geographic area of apple production could be important.

\section{Acknowledgments}

We thank Nan-Yi Wang from University of Florida, Gulf Coast Research and Education Center (GCREC-UF) for laboratory assistance.

\section{Literature Cited}

Adaskaveg, J., and Hartin, R. 1997. Characterization of Colletotrichum acutatum isolates causing anthracnose of almond and peach in California. Phytopathology 87:979-987.

Alaniz, S., Hernandez, L., Damasco, D., and Mondino, P. 2012. First report of Colletotrichum acutatum and C. fragariae causing bitter rot on apple in Uruguay. Plant Dis. 96:458.

Baroncelli, R., Sreenivasaprasad, S., Thon, M. R., and Sukno, S. A. 2014. First report of apple bitter rot caused by Colletotrichum godetiae in the United Kingdom. Plant Dis. 98:1000.

Bernstein, B., Zehr, E. I., Dean, R. A., and Sahabi, E. 1995. Characteristics of Colletotrichum from peach, apple, pecan, and other hosts. Plant Dis. 79:478-482.

Bragança, C. A. D., Damm, U., Baroncelli, R., Massola Júnior, N. S., and Crous, P. W. 2016. Species of the Colletotrichum acutatum complex associated with anthracnose diseases of fruit in Brazil. Fungal Biol. 120:547-561.

Carbone, I., and Kohn, L. M. 1999. A method for designing primer sets for speciation studies in filamentous ascomycetes. Mycologia 91:553-556.

Chen, S. N., Luo, C. X., Hu, M. J., and Schnabel, G. 2016. Fitness and competitive ability of Botrytis cinerea isolates with resistance to multiple chemical classes of fungicides. Phytopathology 106:997-1005.
Damm, U., Cannon, P. F., Woudenberg, J. H. C., and Crous, P. W. 2012a. The Colletotrichum acutatum species complex. Stud. Mycol. 73:37-113.

Damm, U., Cannon, P. F., Woudenberg, J. H. C., Johnston, P. R., Weir, B. S., Tan, Y. P., Shivas, R. G., and Crous, P. W. 2012b. The Colletotrichum boninense species complex. Stud. Mycol. 73:1-36.

Furlan, C. R. C., Dantas, A. C. D. M., Denardi, F., Becker, W. F., and Mantovani, A. 2010. Resistência genética dos acessos do banco de germoplasma de macieira da Epagri à mancha foliar de Glomerella (Colletotrichum gloeosporioides). Rev. Bras. Frutic. 32:507-514.

Gardes, M., and Bruns, T. D. 1993. ITS primers with enhanced specificity for basidiomycetes - application to the identification of mycorrhizae and rusts Mol. Ecol. 2:113-118.

Glass, N. L., and Donaldson, G. 1995. Development of primer sets designed for use with PCR to amplify conserved genes from filamentous ascomycetes. J. Appl. Environ. Microbiol. 61:1323-1330.

Guerber, J. C., Liu, B., Correll, J. C., and Johnston, P. R. 2003. Characterization of diversity in Colletotrichum acutatum sensu lato by sequence analysis of two gene introns, mtDNA and intron RFLPs, and mating compatibility. Mycologia 95:872-895.

Hamada, N. 2013. A Epidemiologia da mancha foliar de glomerella em macieira. Tese, Curitiba, PR

Jiang, J., Zhai, H., Li, H., Wang, Z., Chen, Y., Hong, N., Wang, G., Chofong, G., and $\mathrm{Xu}, \mathrm{W} .2014$. Identification and characterization of Colletotrichum fructicola causing black spots on young fruits related to bitter rot of pear (Pyrus bretschneideri Rehd.) in China. Crop Prot. 58:41-48.

Karaoglanidis, G. S., Luo, Y., and Michailides, T. J. 2011. Competitive ability and fitness of Alternaria alternata isolates resistant to QoI fungicides. Plant Dis. 95: 178-182.

Kou, L. P., Gaskins, V., Luo, Y. G., and Jurick, W. M. 2014. First report of Colletotrichum fioriniae causing postharvest decay on 'Nittany' apple fruit in the United States. Plant Dis. 98:993.

Leite, R. P., Jr., Tsuneta, M., and Kishino, A. Y. 1988. Ocorrência de mancha foliar de Glomerella em macieira no Estado do Paraná. IAPAR, Londrina, Brazil.

Lima, N. B., de A. Batista, M. V., De Morais, M. A., Barbosa, M. A. G., Michereff, S. J., Hyde, K. D., and Câmara, M. P. S. 2013. Five Colletotrichum species are responsible for mango anthracnose in northeastern Brazil. Fungal Divers. 61:75-88.

Ma, B., and Uddin, W. 2009. Fitness and competitive ability of an azoxystrobinresistant G143A mutant of Magnaporthe oryzae from perennial ryegrass. Plant Dis. 93:1044-1049.

MacKenzie, S. J., Peres, N. A., Barquero, M. P., Arauz, L. F., and Timmer, L. W. 2009. Host range and genetic relatedness of Colletotrichum acutatum isolate from fruit crops and leatherleaf fern in Florida. Phytopathology 99:620-631.

Mills, P. R., Sreenivasaprasad, S., and Brown, A. E. 1992. Detection and differentiation of Colletotrichum gloeosporioides isolates using PCR. FEMS Microbiol. Lett. 98:137-143.

Moreira, R. R., and May De Mio, L. L. 2015. Potential biological agents isolated from apple fail to control Glomerella leaf spot in the field. Biol. Control 87:56-63.

Munir, M., Amsden, E., Dixon, E., Vaillancourt, L., and Ward Gauthier, N. A 2016. Characterization of Colletotrichum species causing bitter rot of apple in Kentucky orchards. Plant Dis. 100:2194-2203.

Pasche, J. S., and Gudmestad, N. C. 2008. Prevalence, competitive fitness and impact of the F129L mutation in Alternaria solani from the United States. Crop Prot. 27:427-435.

Peres, N., Souza, N., Peever, T., and Timmer, L. 2004. Benomyl sensitivity of isolates of Colletotrichum acutatum and $C$. gloeosporioides from citrus. Plant Dis. 88:125-130.

Peres, N. A., Mackenzie, S. J., Peever, T. L., and Timmer, L. W. 2008. Postbloom fruit drop of citrus and Key lime anthracnose are caused by distinct populations of Colletotrichum acutatum. Phytopathology 98:345-352.

Petri, J. L., Leite, G. B., Couto, M., and Francescatto, P. 2011. Avanços na cultura da macieira no Brasil. Rev. Bras. Frutic. 33(no. spe1):48-56.

Phoulivong, S., McKenzie, E. H. C., and Hyde, K. D. 2012. Cross infection of Colletotrichum species: A case study with tropical fruits. Curr. Res. Environ. Appl. Mycol. 2:99-111.

Shivas, R. G., and Tan, Y. P. 2009. A taxonomic reassessment of Colletotrichum acutatum, introducing $C$. fioriniae comb. et stat. nov. and $C$. simmondsii $\mathrm{sp}$. nov. Fungal Divers. 39:111-122

Sreenivasaprasad, S., Sharada, K., Brown, A., and Mills, P. 1996. PCR-based detection of Colletotrichum acutatum on strawberry. Plant Pathol. 45: 650-655.

Tamura, K., Peterson, D., Peterson, N., Stecher, G., Nei, M., and Kumar, S. 2011 MEGA5: Molecular evolutionary genetics analysis using maximum likelihood, evolutionary distance, and maximum parsimony methods. Mol. Biol. Evol. 28 2731-2739.

Taylor, J. A. 1971. Epidemiology and symptomatology of apple bitter rot Phytopathology 61:1028-1029.

Van Der AA, H. A. 1978. A leaf spot disease of Nymphaea alba in the Netherlands. Neth. J. Plant Pathol. 84:109-115.

Velho, A. C., Alaniz, S., Casanova, L., Mondino, P., and Stadnik, M. J. 2015 New insights into the characterization of Colletotrichum species associated with apple diseases in southern Brazil and Uruguay. Fungal Biol. 119: 229-244 
Veloukas, T., Kalogeropoulou, P., Markoglou, A. N., and Kalogeropoulou, G. S. 2014. Fitness and competitive ability of Botrytis cinerea field isolates with dual resistance to SDHI and QoI fungicides, associated with several sdhB and the cytb G143A mutations. Phytopathology 104:347-356.

Wang, C. X., Zhang, Z. F., and Li, B. H. 2012. First report of Glomerella leaf spot of apple caused by Glomerella cingulata in China. Plant Dis. 96: 912

Weir, B., Johnston, P. R., and Damm, U. 2012. The Colletotrichum gloeosporioides species complex. Stud. Mycol. 73:115-180.
White, T. J., Bruns, T., Lee, S., and Taylor, R. J. 1990. Amplification and direct sequencing of fungal ribosomal RNA genes for phylogenetics. Pages 315-322 in: PCR Protocols: A Guide to Methods and Applications. M. A. Innis, D. H. Gelfand, J. J. Shinsky, and T. J. White, eds.

Woudenberg, J. H. C., Aveskamp, M. M., Gruyter, J., Spiers, A. G., and Crous, P. W. 2009. Multiple Didymella teleomorphs are linked to the Phoma clematidina morphotype. Persoonia 22:56-62.

Zhan, J., and McDonald, A. 2013. Experimental measures of pathogen competition and relative fitness. Annu. Rev. Phytopathol. 51:131-153. 